\title{
Neither a New Cold War nor a New Peloponnesian War: The Emerging Cyber-narrative Competition at the Heart of Sino-American Relations
}

\author{
Nicholas Ross Smith $\bowtie$, Ruairidh J. Brown \\ University of Nottingham Ningbo, China \\ 凶nr.smith@soverin.net
}

\begin{abstract}
There is much pessimism as to the current state of Sino-American relations, especially since the onset of the COVID-19 pandemic in January 2020. Such pessimism has led to some scholars and commentators asserting that the Sino-American relationship is on the cusp of either a new Cold War or, even more alarmingly, something akin to the Peloponnesian War (via a "Thucydides' Trap") whereby the United States might take pre-emptive measures against China. This article rejects such analogizing and argues that, due to important technological advancements found at the intersection of the digital and fourth industrial revolutions, most of the real competition in the relationship is now occurring in cyberspace, especially with regards to the aim of asserting narratives of "truth". Two key narrative battlegrounds that have raged since the onset of the COVID-19 pandemic are examined: "where was the origin of the COVID-19 pandemic?" and "who has had the most successful response to the COVID-19 pandemic?". This article shows that Sino-American competition in cyberspace over asserting their narratives of truth (related to the COVID-19 pandemic) is fierce and unhinged. Part of what is driving this competition is the challenging domestic settings politicians and officials find themselves in both China and the United States, thus, the competing narratives being asserted by both sides are predominately for domestic audiences. However, given that cyberspace connects states with foreign publics more intimately, the international aspect of this competition is also important and could result in further damage to the already fragile Sino-American relationship. Yet, whether this competition will bleed into the "real world" is far from certain and, because of this, doomsaying via historical analogies should be avoided.
\end{abstract}

Key words: Sino-American competition, New Cold War, Thucydides’ Trap, cyberspace, COVID-19

For citation: Smith, N.R., \& Brown, R.J. (2021). Neither a New Cold War nor a New Peloponnesian War: The Emerging Cyber-narrative Competition at the Heart of Sino-American Relations. Vestnik RUDN. International Relations, 21(2), 252-264. https://doi.org/10.22363/2313-0660-2021-21-2-252-264

\section{Ни новая холодная война, ни новая Пелопоннесская война: зарождающееся кибернарративное соперничество в центре американо-китайских отношений}

\author{
Н.Р. Смит $ه$, Р.Д. Браун \\ Ноттингемский университет, кампус Нинбо, Нинбо, Китай \\ \nr.smith@soverin.net
}

\begin{abstract}
Аннотация. В отношении текущего состояния американо-китайских отношений, особенно после начала пандемии COVID-19 в январе 2020 г., царят пессимистические настроения. Такой пессимизм привел к тому, что некоторые ученые и комментаторы утверждают, что американо-китайские отношения находятся
\end{abstract}

(C) Smith N.R., Brown R.J., 2021

This work is licensed under a Creative Commons Attribution 4.0 International License.

https://creativecommons.org/licenses/by/4.0/ 
на пороге либо новой холодной войны, либо, что еще более тревожно, подобия Пелопоннесской войны (в рамках «ловушки Фукидида»), в результате чего США могут принять превентивные меры против Китая. Эта статья отвергает такое сопоставление и утверждает, что из-за важных технологических достижений, произошедших на пересечении цифровой и четвертой промышленных революций, реальная конкуренция во взаимоотношениях между государствами сейчас преимущественно происходит в киберпространстве, особенно в том, что касается утверждения нарративов об «истине». Исследуются два ключевых поля «битв нарративов», которые происходят с момента начала пандемии COVID-19: «Откуда взялась пандемия COVID-19?» и «Кто наиболее успешно отреагировал на пандемию COVID-19?». Показано, что американокитайская конкуренция в киберпространстве за отстаивание своих правдивых нарративов (связанных с пандемией COVID-19) является жесткой и беспорядочной. Частично это противостояние развивается в сложных внутригосударственных условиях, в которых политики и чиновники оказываются как в Китае, так и в США. Таким образом, конкурирующие нарративы, утверждаемые обеими сторонами, в основном предназначены для внутренней аудитории. Однако, учитывая, что киберпространство более тесно связывает государства с мировой общественностью, международный аспект этой конкуренции также важен и может нанести еще больший ущерб и без того хрупким американо-китайским отношениям. Тем не менее на данный момент не ясно, распространится ли это противостояние на «реальный мир», и по этой причине следует избегать использования исторических аналогий для трактовки современных американо-китайских отношений.

Ключевые слова: американо-китайское соперничество, новая холодная война, «ловушка Фукидида», киберпространство, COVID-19

Для цитирования: Smith N.R., Brown R.J. Neither a New Cold War nor a New Peloponnesian War: The Emerging Cyber-narrative Competition at the Heart of Sino-American Relations // Вестник Российского университета дружбы народов. Серия: Международные отношения. 2021. Т. 21. № 2. С. 252-264. DOI: $10.22363 / 2313-0660-2021-21-2-252-264$

\section{Introduction}

The visible straining of the Sino-American relationship in recent years has elicited significant media and academic attention. The basic consensus is that since the establishment of positive diplomatic relations between the United States and China in the late 1970s, the United States' efforts to encourage China to develop and rise along a "liberal" trajectory, and thus become a proactive member of a US-led international order, have failed. Rather, despite overtures of rising peacefully and talk of international leadership based on the principle of cooperation over competition, the view is that China has emerged as a competitor to the United States' position as the unquestioned international hegemon and the prime arbiter of international order. In an era where Sino-American relations have become blighted by trade wars, diplomatic spats, and, to an extent, increased military power projection in the Asia-Pacific region, there is, rightly, significant pessimism as to the future of the Sino-American relationship. To this end, two popular analogies have emerged as to where the Sino-American relationship is heading: a new Cold War or a new Peloponnesian War.
Characterizing China and the United States as on the cusp of a new Cold War has become an extremely popular analogy in recent years ${ }^{1}$. Simply put, this argument asserts that China and the United States in the coming years will enter a period of significant competition, and potentially even engage in proxy wars, a la the Soviet Union and the United States in the post-WWII setting [Li 2020]. On the surface, there are, indeed, some interesting parallels between the original Cold War and the current state of the SinoAmerican relationship. Firstly, it seems inevitable that the international system is transitioning away from a unipolar system to a nascent bipolar one [Schweller, $\mathrm{Pu}$ 2011], although this remains a glacial transition (unlike previous power transitions which were "epochal") [Smith 2019].

${ }^{1}$ Rachman G. A new cold war: Trump, Xi and the escalating US-China confrontation // The Financial Times. October 4, 2020. URL: https://www.ft.com/content/ 7b809c6a-f733-46f5-a312-9152aed28172 (accessed: 20.01.2021); Dupont A. The US - China Cold War Has Already Started // The Diplomat. July 08, 2020. URL: https://thediplomat.com/2020/07/the-us-china-cold-warhas-already-started/ (accessed: 20.01.2021). See also: [Sachs 2019]. 
Secondly, threat-perceptions on both sides have become noticeably more pessimistic and darker in recent years ${ }^{2}$, which potentially creates something akin to the twisted "mirror image" of negative perceptions that characterized the early days of the original Cold War [Bronfenbrenner 1961].

And lastly, China has seemingly made efforts to start building its own international order (or bloc) through initiatives such as Belt and Road Initiative (BRI) and the Asian Infrastructure Investment Bank (AIIB) [Clarke 2017; Thaliyakkattil 2019], which has the potential to usher in a period of global bipolarization (i.e. the creation of rival blocs) like in the 1950s [Rapkin, Thompson, Christopherson 1979].

More pessimistically than a vision of a new Cold War, some have used the Peloponnesian War as an analogy, most commonly articulated as the "Thucydides' Trap" [Allison 2017], for the state of Sino-American relations [Moore 2017; Yoder 2019; Zhang 2019]. This vision asserts that the United States could be forced to undertake a pre-emptive attack on China, a la Sparta against Athens during the Peloponnesian War, to prevent it from challenging American hegemony [Allison 2017].

Again, on the surface, there is some logic to the Thucydides' Trap argument: China is rising at a rapid pace that threatens the long-term status of the United States, and, at this moment, the United States retains a significant power advantage that might make the idea of a preemptive attack seem strategically feasible in Washington. Arguably, Trump's decision to wage a succession of trade wars against China, beginning in 2018, was an attempt by the United States to use its power advantage (in this case, perceived economic and trade advantages) to inflict damage on China [Moosa 2020]. The onset of COVID-19 and the increase in tension it has caused between the United States and China has, in the minds of some, further increased the

\footnotetext{
${ }^{2}$ Silver L., Devlin K., \& Huang C. Unfavorable Views of China Reach Historic Highs in Many Countries // Pew Research Center. October 6, 2020. URL: https://www.pewresearch.org/global/2020/10/06/unfavorab le-views-of-china-reach-historic-highs-in-many-countries/ (accessed: 20.01.2021). See also: [Meng 2019].
}

potential for a Peloponnesian War type scenario because it has completely eroded any trust or good will left in the relationship, leaving mostly animosity left, potentially exacerbating the underlying structural drivers for a pre-emptive attack of sorts ${ }^{3}$.

The emergence of such thinking is unsurprising because historical analogising has long been a popular analytical tool in both journalism and academia. However, this article argues that both the Cold War and Peloponnesian War analogies are not fit for purpose when examining the current state of the Sino-American relationship. The problem with looking to the past to provide an analytical lens for the present is that, to make it work, one must cut significant corners and engage in reductivism. The individuals, units, systems, ideologies, and psychologies of any one time and space are different from the individuals, units, systems, ideologies, and psychologies of any other time and space. Of course, the Sino-American relationship is undoubtedly affected by pressures and conditions that are somewhat analogous with either the Cold War or the Peloponnesian War. It is also undeniable that China's rise is causing serious consternation in Washington leading it to consider different strategies. All the time the transition of the international system towards bipolarity is creating ripples which are being felt in both Washington and Beijing. However, this is a unique situation which requires a unique lens to examine.

\section{The Technological Advancement of Cyberspace and Its Effect on Great Power Competition}

Part of the uniqueness of the current cooling of the Sino-American relationship lies in the

${ }^{3}$ See: Brown K. For the US and China, Thucydides' Trap Is Closing // The Diplomat. June 11, 2020. URL: https://thediplomat.com/2020/06/for-the-us-and-chinathucydides-trap-is-closing/ (accessed: 20.01.2021); Tang Y. As a second wave looms, the US and China must escape the coronavirus 'trap' and work together to avert disaster // South China Morning Post. July 4, 2020. URL: https:/www.scmp.com/comment/opinion/article/3091422/ second-wave-looms-us-and-china-must-escapecoronavirus-trap-and (accessed: 20.01.2021). 
technological landscape of the contemporary world. Technological advancement has been a key component in determining the nature of the interaction between different units since the dawn of humanity. For instance, Neumann [2018] argues that a crude form of diplomacy first emerged in prehistoric times due to the technological developments - namely advances during the stone age - which enabled big game hunting. But, importantly, the success of the hunt was predicated on the cooperation of groups which necessitated a kind of diplomacy. As Sai Felicia Krishna-Hensel [2010] argues, technological advancement "increases the options available to policymakers in their pursuit of the goals of the state, but also complicates their decision making".

The most important recent technological development for international politics has arguably been the "digital revolution" which began during the Cold War and has continued to evolve at an exponential rate since. The most notable manifestation of the digital revolution has been the continued advances in computer technology, especially the internet and the spread of access to the internet across the globe. Klaus Schwab, the founder of the World Economic Forum, has argued that the digital revolution what he terms the third industrial revolution is currently giving way to a fourth industrial revolution: "a fusion of technologies that is blurring the lines between the physical, digital, and biological spheres"4. One key product of the digital revolution - an area which is accelerated and changed by the ongoing fourth industrial revolution - for international politics has been the creation of a new realm of human interaction, one which also extends to international politics: cyberspace.

Michael Benedikt [1994: 123] defines cyberspace as a "globally networked, computersustained, computer-accessed, and computergenerated, multidimensional, artificial, or 'virtual' reality". The growth and proliferation of

\footnotetext{
${ }^{4}$ Schwab K. The Fourth Industrial Revolution: what it means and how to respond // World Economic Forum. January 14, 2016. URL: https://www.weforum.org/agenda/ 2016/01/the-fourth-industrial-revolution-what-it-meansand-how-to-respond/ (accessed: 21.01.2021).
}

individuals accessing cyberspace has been significant since the mid-1990s. As of 2019, $51 \%$ of the globe $(87 \%$ of people in developed countries versus $44 \%$ of people in developing countries) with a total cyberspace population of around 4 billion individuals ${ }^{5}$. Beyond individual use, cyberspace has also grown into a crucial network for the functioning of machines the "internet of things" - and has become a significant area for economic activity: the "digital economy" now roughly accounts for $15 \%$ of global GDP.

The international relations of cyberspace is a challenging arena to observe because interactions in cyberspace are much more opaque than in the "real world", so knowing who is behind an action, or actions, can be difficult [Choucri, Goldsmith 2012]. Furthermore, as Jairus Grove [2020: 436] argues, beyond the traditional actors found in the international politics, with the advent of this so-called fourth industrial revolution "the range of actors include algorithms, robots, the collective and space / time altering character of the internet of things as well as the aspirational planning for general artificial intelligence to govern the swarms of machinic life and potentially humans as well". States are still the prime actors, especially greater powers, but their power is not as obvious as in the "real world" and is probably diminishing as time goes by, especially with the growth of tech giants like Apple, Alibaba, Alphabet, Tencent, Facebook and Microsoft [Cartwright 2020]. Importantly, as evident in the preceding list, there is a clear U.S. - China dichotomy emerging in these tech giants, with the closeness of the Chinese Communist Party to their tech giants a particular international concern?

\footnotetext{
5 Statistics of ITU-D // International Telecommunication Union. 2019. URL: https://www.itu.int/ en/ITU-D/Statistics/Pages/stat/default.aspx (accessed: 21.01.2021).

6 Digital Economy Report 2019 // UNCTAD. 2019. URL: https://unctad.org/system/files/official-document/ der2019_en.pdf (accessed: 21.01.2021).

${ }^{7}$ Dorfman Z. Tech giants are giving China a vital edge in espionage // Foreign Policy. December 23, 2020. URL: https://foreignpolicy.com/2020/12/23/china-tech-giantsprocess-stolen-data-spy-agencies/ (accessed: 21.01.2021).
} 
Importantly, though, unlike in the "real world" where the putative Westphalian system is (still) mediated by the presence of nuclear weapons, economic interdependence, multilateralism, and agreed norms, cyberspace is undoubtedly an area where competition between states is at its most ferocious ${ }^{8}$. Because of this, states, especially greater powers, have invested significantly in increasing cyber capabilities in the most recent decade, not only for the pursuit of diplomacy but also for war. Cyber diplomacy, as Barrinha and Renard [2017: 353] observe, has become pivotal in the day-to-day business of international politics because "most global powers have now streamlined cyber issues into their foreign policies, adopting cyber strategies and appointing designated diplomats to pursue these strategic objectives". Regarding conflict and warfare, arguably at first, cyber-attacks were mostly conducted by disgruntled states like China, Russia, Iran, or North Korea or groups of hackers (often known as "hacktivists") such as the "Legion of Doom" or "Anonymous" [Middleton 2017]. But, since the mid-2000s, after growing increasingly paranoid about its vulnerability to cyber-attack (especially from China and Russia), the United States has invested heavily in increasing its cyber capabilities, sparking something of a cyber "arms race" [Demchak, Dombrowski 2014; Limnéll 2016].

\section{The COVID-19 Pandemic and the Ensuing Battle of Narratives in Cyberspace}

In the context of Sino-American competition in cyberspace, much attention has focused on the material aspect of this competition, especially in recent times with a spike of interest around 5G technology and the permutations of this for international security [Cartwright 2020]. However, this article argues that where competition in cyberspace is perhaps the most unhinged right now is in the ideational

8 Wheeler T. In Cyberwar, There are No Rules // Foreign Policy. September 12, 2018. URL: https://foreignpolicy.com/2018/09/12/in-cyberwar-thereare-no-rules-cybersecurity-war-defense/ (accessed: 21.01.2021). See also: [Diesen 2021; Huseynov 2019; Smith 2020]. realm, particularly with regards to the assertion of narratives.

The notion that narratives (and in some ways, the "truth") could be competed over in cyberspace became more prominent in the wake of the 2016 US presidential election where Russia was alleged to have helped the Trump campaign, in part, through propagating (and disseminating) information (some obtained illegally through a cyber-attack on the Democratic National Congress) in cyberspace that smeared the Democratic nominee, Hilary Clinton. Whether it was pivotal to Trump's victory or not, what the 2016 US presidential election fiasco demonstrated was how cyberspace could be used by states to manage the perceptions of publics (both domestic and foreign) [Polyakova, Boyer 2018]. And like in the "real world", states are similarly confronted with something of a two-level game in cyberspace as they have to balance their domestic game, that is domestic state-society relations, with their international game, that is international diplomatic strategy and activities [Bjola, Manor 2018]. The problem in recent years, however, is that the domestic settings of many states - China and the United States included - have become beset by rising nationalism which arguably intensifies the battle of narratives [Jaworsky, Qiaoan 2020].

Competing narratives are not uncommon to the Sino-American relationship, especially in cyberspace. Over the years, both sides have asserted alternative narratives on topics such as the Tiananmen Square massacre, the North Korea issue, and more recently, Hong Kong. However, it is arguably with the onset of the COVID-19 pandemic in January 2020 that a battle of narratives between the United States and China became extremely competitive [Jaworsky, Qiaoan 2020], and this was especially evident in cyberspace. Two key narrative battles have emerged over the COVID-19 pandemic: one over the origin of the virus and one over the response to the virus.

\section{Narrative Battle \#1:}

\section{The Origin of the COVID-19 Pandemic}

As the severity of COVID-19 and its potential to evolve into a pandemic became 
known, one of the key narrative battles that instantly beset Sino-American relations in cyberspace was to do with the origin of the virus and whether China was to blame for the pandemic or not. As the situation worsened in the United States - cases started to spike in March and have, as of January 2021, continued to remain high — its leadership made a conscious effort to reiterate that the virus had its origins in China. Then United States President, Donald Trump, repeatedly labelled COVID-19 the 'China Virus'. Tellingly, Trump used the term publicly approximately five hundred times in $2020^{9}$. Trump also used a series of other terms, albeit it less frequently, to stress a 'Chinese' nature to the virus: the 'China Plague' (used approximately three hundred and fifty times); 'Kung Flu' (used approximately five times) and the 'Wuhan virus' (used approximately three times $)^{10}$. That Trump deliberately intended to target China was seemingly further revealed when a photographer captured Trump's White House briefing notes, the word 'corona' crossed out and replaced with 'Chinese'11. Trump was not alone, however, in identifying the virus as a threat emanating from China. Then United States Secretary of State, Mike Pompeo, notably caused friction with other G7 ministers by insisting on calling the virus the "Wuhan virus whereas the other six members preferring 'COVID-19' as was favoured by WHO, resulting in the group failing to make a joint statement ${ }^{12}$.

In addition to asserting a narrative that the virus was of Chinese origin, United States officials further asserted that its spread had been aided by an attempted cover-up by the Chinese

\footnotetext{
${ }^{9}$ Donald Trump Complete - Best Tweets, Speeches, Policies // FactSquared. URL: https://factba.se/trump/ search\#Donald\%2BTrump (accessed: 25.01.2021).

${ }^{10}$ Ibid.

${ }^{11}$ Chiu A. Trump calling coronavirus 'Chinese virus' encourages racism against Asian Americans, experts say // The Washington Post. March 20, 2020. URL: https://www.washingtonpost.com/nation/2020/03/20/coron avirus-trump-chinese-virus/ (accessed: 25.01.2021).

12 Graziosi G. Coronavirus: Mike Pompeo insists G7 use "Wuhan Virus" - but world officials refuse // The Independent. March 25, 2020. URL: https:/www.independent. co.uk/news/coronavirus-g7-wuhan-virus-mike-pompeotrump-a9426261.html (accessed: 25.01.2021).
}

Communist Party (CCP). Pompeo asserted that the CCP was engaged in a "disinformation campaign" to "try and deflect from what has really taken place" $"$. Pompeo continued to attack China thereafter, remarking in a public speech at the Nixon Presidential Library that China had a 'virulent strain' of communism and that the world would have been 'much better' if 'we had been able to hear from the doctors in Wuhan and they'd been allowed to raise the alarm' ${ }^{14}$. Such accusations also mirror the language and narrative of Trump. In May 2020, Trump, in a tweet, publicly admonished China for "incompetence" and its role in "mass Worldwide killing!"15.

Much of the narratives asserted by the United States online, especially via Trump and Pompeo, attempted to establish the "truths" that not only did the virus originate in China, but the CCP could have prevented the pandemic. Nonetheless, some narratives were more conspirational, including a prominent "fringe" narrative that asserted that China deliberately developed the virus as a kind of biological weapon to hurt the United States. Although this theory was most prominent in conservative and far-right circles, such as Republican Senator, Tom Cotton, and the website Townhall ${ }^{16}$, Trump and his wider support network still gave some credence to the theory. A report by the Australia Institute's Centre for Responsible Technology identified a coordinated use of social media by pro-Trump accounts to spread disinformation

13 Pompeo says G7 discussed China's coronavirus “disinformation" // Reuters. March 25, 2020. URL: https://www.reuters.com/article/uk-heath-coronaviruspompeo-china-idUKKBN21C2N3 (accessed: 25.01.2021).

14 Pompeo M.R. Communist China and the Free World's Future // U.S. Department of State. July 23, 2020. URL: https://2017-2021.state.gov/communist-china-andthe-free-worlds-future-2/index.html (accessed: 25.01.2021).

15 Trump blames China for "mass Worldwide killing" // France24. May 20, 2020. URL: https://www.france24.com/ en/20200520-trump-blames-china-for-mass-worldwidekilling (accessed: 25.01.2021).

${ }^{16}$ Baumann B. Why the State Department Is Raising New Concerns about COVID's Origination // Townhall. January 17, 2021. URL: https://townhall.com/tipsheet/ bethbaumann/2021/01/17/state-department-raises-majorflags-about-the-wuhan-institute-of-virologys-rolen2583272 (accessed: 25.01.2021). 
propagating the "China bioweapon conspiracy theory" 17 .

The commonality of all these narratives, no-matter the severity of the blame they placed on China, was that they sought to keep the focus on China while absolving the United States of any blame for their apparent mishandling of the pandemic at home.

China was neither idle nor passive in responding to the narratives being asserted by the United States. Chinese officials and Chinese state media began by angrily responding to American accusations and association of the virus with China. In early May 2020, China's Ambassador to the United States, Cui Tiankai, wrote a retort in the Washington Post, lambasting the language emanating from Trump and Washington while characterising the habit of 'always blame China' as an 'absurd mindset' behind which lay 'dirty politics' ${ }^{18}$. Chinese State media meanwhile reserved particular anger for Pompeo, even calling into question his Christian Faith. The China Daily published an opinion piece which had the headline "Pompeo's remarks not befitting of a Christian" and was accompanied by a cartoonist's rendering of Pompeo's Christian façade being a cover for American lies and cheating ${ }^{19}$.

Beyond angry retorts, however, China has also embarked in a more ambitious endeavour to shift what seemed to be a foundational truth about the pandemic: that it originated in China. One of China's most prominent officials on

${ }^{17}$ Graham T., Bruns A., Zhu G., Campbell R. Like a virus: The coordinated spread of coronavirus disinformation // Centre for Responsible Technology of the Australian Institute. May 2020. URL: https://d3n8a8pro7 vhmx.cloudfront.net/theausinstitute/pages/3316/attachment s/original/1590956846/P904_Like_a_virus_-_COVID19 disinformation_Web_.pdf? $15909 \overline{5} 6 \overline{8} 46^{-}$(accessed: 25.01.2021).

${ }^{18}$ Cui T. Chinese ambassador Cui Tiankai: Blaming China will not end this pandemic // The Washington Post. May 6, 2020. URL: https://www.washingtonpost.com/ opinions/chinese-ambassador-cui-tiankai-blaming-chinawill-not-end-this-pandemic/2020/05/05/4e1d61dc-8f0311 ea-a9c0-73b93422d691 story.html (accessed: 25.01.2021).

19 Wei D. Pompeo's remarks not befitting of a Christian // China Daily. June 24, 2020. URL: https:/www.chinadaily.com.cn/a/202006/24/WS5ef29805a 310834817255044.html (accessed: 25.01.2021).
Twitter (with more than 800,000 followers), Zhao Lijian, tweeted that 'It might be US army who brought the epidemic to Wuhan', suggesting not only was the true origin of the virus the United States but the outbreak in China was some form of military attack ${ }^{20}$. Indeed, this narrative mirrors the "China bioweapon conspiracy theory" being pushed by fringe elements in the United States, although in China's case it came directly from a government spokesperson. However, beyond simply blaming the United States, China has sought to cast doubt about the Chinese origins of COVID-19 by suggesting multiple different possible origins for the virus. In November 2020, for example, the Global Times (a state-owned English language newspaper) ran an article about how a cuttingedge scientific inquiry by Chinese researchers had found evidence that the Indian subcontinent may have been the true origin of the first COVID-19 transmission ${ }^{21}$. The paper was removed at the request of the authors before it could receive peer review, however, this did not prevent it from making global news.

Whilst the two examples mentioned above demonstrate attempts to identify the origins of COVID-19 with countries China has had recent tensions with, the United States and India, there have also been endeavours to identify the origins of the virus in nations China has concurrently been attempting to cultivate friendships with (friendliness is an important narrative pushed by China, globally), most notably Italy. When Italy was seriously affected by the virus, and the United States and the European Union seemed unwilling to help, China had offered supplies and solidarity with Italy in an effort that has been regarded an attempt to demonstrate global leadership and establish China as a caring, humanitarian power [Smith, Fallon 2020]. Yet, despite these efforts, when the opportunity arose, the Chinese state news agency, Xinhua,

${ }^{20}$ China government spokesman says U.S. army might have brought virus to China // Reuters. March 12, 2020. URL: https://www.reuters.com/article/us-health-coronaviruschina-ministry-idUSKBN20Z2HJ (accessed: 25.01.2021).

${ }^{21}$ Liu C., Fan A. More evidence supports multiple virus origins // Global Times. November 29, 2020. URL: https://www.globaltimes.cn/content/1208404.shtml (accessed: 25.01.2021). 
identified Italy in December 2020 as the actual ground zero of the pandemic ${ }^{22}$. More recently, in January 2021, Xinhua suggested that COVID-19 had appeared in 'multiple' countries before China, citing that the virus had been found on samples of imported frozen food packaging ${ }^{23}$. This seems to be a somewhat desperate strategy of using multiple narratives as a kind of "carpet bomb", as by offering multiple potential origins of the COVID-19 pandemic, China was hoping that it could, if not disprove, obfuscate the widely accepted narrative that it began in Wuhan in December 2019.

\section{Narrative Battle \#2: China Has Been the Most Successful in Responding to the Pandemic}

Whereas the narrative battle examined above was a case of the United States asserting a narrative and China responding, a second narrative battle emerged out of this and centred around the narrative of which country has had the best response to the COVID-19 pandemic. However, unlike the first narrative battle, this one was asserted by China, with the United States responding. Once China had managed to get the COVID-19 outbreak under control, around late February, it sought to divert attention away from narratives of 'origins' toward narratives of 'solutions'. A common narrative put forward by Chinese state media outlets and officials is that while determining the origins of the virus may help us deal with it, it is not the most effective way because stopping the outbreak is now clearly more important than blaming it on others ${ }^{24}$. Indeed, in the May 2020

22 Hernandez J.C. China Peddles Falsehoods to Obscure Origin of COVID Pandemic // The New York Times. December 6, 2020. URL: https://www.nytimes.com/ 2020/12/06/world/asia/china-covid-origin-falsehoods.html (accessed: 25.01.2021).

23 Science, and only science, in COVID-19 origintracing // Xinhua. January 14, 2021. URL: http://www.xinhuanet.com/english/2021-01/14/c_13966 7230.htm (accessed: 25.01.2021).

24 Coronavirus may have existed in Italy since November: local researcher // CGTN. March 22, 2020. URL: https://news.cgtn.com/news/2020-03-22/Coronavirusmay-have-existed-in-Italy-since-November-localresearcher-P4i2As2OAg/index.html (accessed: 25.01.2021).
Washington Post opinion piece written by China's Ambassador to the United States, Cui Tiankai remarked that the 'blame China' attitude is hurting efforts to fight the disease ${ }^{25}$. This is a point that continues to be reiterated in 2021 , as a recent Xinhua article stressed that Western 'rumour spreading' over origins covers up their failings and inhibits the world from controlling the spread of the virus ${ }^{26}$. Additionally, China's continued stymying of a transparent World Health Organization (WHO) probe could be seen as a way of trying to keep the focus on solutions ${ }^{27}$.

China feels more confident discussing the topic of solutions than the topics of origins. Indeed, foundational to the CCP's narrative on the virus is that China has found COVID-19's kryptonite: Xi Jinping thought and China's Socialist system. As early as March, Chinese State media was declaring a victory over COVID-19, attributing success to a combination of Xi's leadership and thought and Chinese socialist system which allowed for rapid mobilisation and solidarity ${ }^{28}$ China's 'institutional advantages' were particularly praised as a key difference between China's 'low death rate' compared to western liberal States ${ }^{29}$. Special praise was, however, reserved for Xi. Xinhua published a chronicle of Xi's leadership, praising him for tirelessly taking the lead and

${ }^{25}$ Cui T. Chinese ambassador Cui Tiankai: Blaming China will not end this pandemic // The Washington Post. May 5, 2020. URL: https://www.washingtonpost.com/ opinions/chinese-ambassador-cui-tiankai-blaming-chinawill-not-end-this-pandemic/2020/05/05/4e1d61dc-8f0311ea-a9c0-73b93422d691_story.html (accessed: 25.01.2021).

26 Science, and only science, in COVID-19 origintracing // Xinhua. January 14, 2021. URL: http://www.xinhuanet.com/english/2021-01/14/c_13966 7230.htm (accessed: 25.01.2021).

${ }^{27}$ Shepherd C. China blocks WHO team sent to probe COVID's origins // The Financial Times. January 06, 2021. URL: https://www.ft.com/content/7e9ce61d-7b72456b-a2e4-48b167bfd394 (accessed: 26.01.2021).

${ }^{28}$ Xi leads people's war on epidemic // Xinhua. March 12, 2020. URL: https://www.chinadailyhk.com/article/ 124100 (accessed: 31.01.2021).

29 Low death rate from China's institutional advantages: China Daily commentary // China Daily. April 17, 2020. URL: https:/global.chinadaily.com.cn/a/202004/ 17/WS5e994c05a3105d50a3d16ff4.html (accessed: 31.01.2021). 
mobilising China in the 'people's war' against the 'invisible enemy'30. And beyond Xi's leadership qualities, his own thoughts and, especially, his ability to govern via a system of Socialism with Chinese Characteristics, were deemed essential elements of ensuring the nation's victory.

Although the seemingly excessive lauding of $\mathrm{Xi}$ might appear to be purely for domestic audiences, sections of foreign publics, even in the West, have shown admiration for "strongmen" leaders like Xi and Putin and often there is a craving for strong leadership in a time of crisis. The same is true of China's authoritarian rule as COVID-19 hit at a time of significant Western disillusionment with regards democracy, making some foreign publics perhaps more receptive than usual. And importantly, the international audience in China's narratives was not ignored. China's Minister of Foreign Affairs, Wang Yi, has consistently emphasised that China has won 'international admiration' due to its successful defeat of the virus and that its model of strong leadership (Xi) and system (Socialism with Chinese Characteristics) are models other countries can follow ${ }^{31}$. Indeed, an emerging narrative pushed by China is that its practices during the pandemic should be a source of guidance for other countries on how to put people first and tackle challenges for the international community ${ }^{32}$. To this end, the CCP

${ }^{30}$ Xi Focus: Chronicle of Xi's leadership in China's war against coronavirus // Xinhua. September 07, 2020. URL: http://www.xinhuanet.com/english/2020-09/ 07/c 139349538.htm (accessed: 26.01.2021).

$3 \overline{1}$ See: Wang Y. Following Xi Jinping Thought on Diplomacy To Build a Community with a Shared Future for Mankind Through International Cooperation Against COVID-19 // Ministry of Foreign Affairs of the People's Republic of China. April 19, 2020. URL: https://www.fmprc.gov.cn/mfa_eng/zxxx_662805/t177125 7.shtml (accessed: 26.01.2021); Wang Y. Resolutely Defeating the COVID-19 Outbreak and Promoting the Building of a Community with a Shared Future for Mankind // Ministry of Foreign Affairs of the People's Republic of China. March 02, 2020. URL: https://www.fmprc.gov.cn/mfa_eng/wjb_663304/wjbz_663 308/2461_663310/t1751673.shtml (accessed: 26.01.2021).

$32 \mathrm{He}^{-} \mathrm{Y}$. China's governance contributes wisdom, power to world // People's Daily Online. May 26, owned 'Central Compilation and Translation Press' recently published in English a book by $\mathrm{Xi}$ Jinping titled 'Discourses on coordinating epidemic control with economic, social development', which is touted as a manual to help other countries fight the COVID-19 pandemic ${ }^{33}$.

In response to China's narratives of success in fighting the COVID-19 outbreak, the United States was initially complimentary. When the outbreak of COVID-19 became international news, Trump was extremely positive about the Chinese response and reserved extensive praise for Xi. For instance, in early February, Trump tweeted: "Just had a long and very good conversation by phone with President $\mathrm{Xi}$ of China. He is strong, sharp and powerfully focused on leading the counterattack on the Coronavirus" 34 .

Trump's effusive praise for China was complemented by his desire to downplay the severity of the virus for much of early 2020, and thus not wish to see it as a 'threat' (regardless of if it came from China or not). However, as the situation worsened domestically in the United States, Trump and officials started to change their narratives in March 2020. A tipping point of this was arguably Zhao Lijian's controversial tweet on March 12 which accused the US army of bringing the virus to Wuhan. Trump appeared to be personally upset by the tweet ${ }^{35}$. And although Trump remained somewhat loyal to $\mathrm{Xi}$ - he notably praised $\mathrm{Xi}$ when campaigning for the 2020 US presidential election - China's

2020. URL: http://en.people.cn/n3/2020/0526/c900009694393.html (accessed: 31.01.2021).

33 Xi's discourses on coordinating epidemic control with economic, social development published in English // Xinhua. December 13, 2020. URL: http://www.xinhuanet.com/ english/2020-12/13/c_139586146.htm (accessed: 26.01.2021).

34 Ward M. $\overline{15}$ times Trump praised China as coronavirus was spreading across the globe // POLITICO. April 15, 2020. URL: https://www.politico.com/news/ 2020/04/15/trump-china-coronavirus-188736 (accessed: 26.01.2021).

35 Viala-Gaudefroy J., Lindaman D. Donald Trump's 'Chinese virus': the politics of naming // The Conversation. April 21, 2020. URL: https://theconversation.com/donaldtrumps-chinese-virus-the-politics-of-naming-136796 (accessed: 26.01.2021). 
claims about its successes in combatting COVID-19 became more heavily scrutinized and rebuked by the United States. In a classified intelligence report to the White House that was leaked in early April, and widely reported online, China was accused of "under-reporting both total cases and deaths it's suffered from the disease" 36 .

The United States and some of its partners, such as the EU, took even stronger steps to try and counter Chinese narratives about its success in fighting COVID-19. As mentioned earlier in this section, China had sought to gain international adulation for its humanitarian efforts - widely known as mask diplomacy and part of their narrative was highlighting that other powers, such as the United States and the EU, were absent in the time of need of countries like Italy, Spain, and Serbia [Smith, Fallon 2020]. The European Commission was the first to consciously attempt to fight this "disinformation" by providing factual evidence of China's support for European countries vis-à-vis the EU's support ${ }^{37}$. Meanwhile, the United States followed suit, utilising the State Department's 'Global Engagement Center', an interagency entity that had been set up in 2016 to counter the efforts of international terrorist groups but had become mostly occupied with countering perceived Russian disinformation efforts concerning the 2016 US presidential election. In early May 2020, Lea Gabrielle, head of the Global Engagement Center, warned of there being a "one-way megaphone from the Chinese Communist Party into free, open and democratic societies" which was pushing a "disturbing convergence of narratives" about the COVID-19 pandemic ${ }^{38}$. And perhaps as a sign of a greater

${ }^{36}$ Wadhams N., Jacobs J. China Concealed Coronavirus Outbreak Extent: U.S. Intelligence // Bloomberg. April 01, 2020. URL: https://www.bloomberg.com/news/articles/ 2020-04-01/china-concealed-extent-of-virus-outbreak-u-sintelligence-says (accessed: 26.01.2021).

37 Fighting disinformation // European Commission. URL: https://ec.europa.eu/info/live-work-travel-eu/coronavirusresponse/fighting-disinformation_en\#separating-fact-fromfiction-on-covid-19 (accessed: 26.01.2021).

38 Shinkman P.D. State Department: China Working With Russia to Spread Coronavirus Disinformation on Twitter. // U.S. News. May 8, 2020. URL: https:/www.usnews.com/news/world-report/articles/2020- pushback against Chinese narratives is to follow, new United States president, Joseph Biden, has tabbed a noted China disinformation expert, Laura Rosenberger, for a position in his National Security Council team ${ }^{39}$.

\section{Discussion}

This article's brief analysis of two of the main narrative battles that have occurred between China and the United States in cyberspace since the onset of the COVID-19 pandemic demonstrates that there is significant competition between the two in this area. Of course, part of what is driving this competition is the challenging domestic settings politicians and officials find themselves in both China and the United States. Because of this, much of the narratives being asserted by both sides are predominately for domestic audiences.

However, the international aspect of this should not be entirely eschewed from analysis because both sides have a lot on the line with regards their international reputation and, unlike in the Cold War, cyberspace connects states with foreign publics more intimately. In China's case, it had the potential to become an internationally respected humanitarian power; an inspiring country which successfully defeated the virus without much cost while simultaneously helping more heavily afflicted countries through largesse and advice. In the United States' case, it had the potential to lose even more if its international reputation which had reached new depths under the presidency of Trump; a bumbling country that, despite its wealth and power, was unable to prevent a domestic disaster or help any of its purported friends and allies.

After 12 months of the COVID-19 pandemic, it appears that both China and the United States have failed in asserting their narratives internationally and are, in a way, both

05-08/state-department-china-working-with-russia-tospread-coronavirus-disinformation-on-twitter (accessed: 26.01.2021)

39 Brennan D. Joe Biden Taps China Coronavirus Disinformation Expert for NSC // Newsweek. January 15, 2021. URL: https://www.newsweek.com/joe-biden-tapschina-coronavirus-disinformation-expert-nsc-laurarosenberger-1561885 (accessed: 26.01.2021). 
losers. In the case of the first narrative battle over the origin of the virus, China's attempts to cast doubt over Wuhan being the origin of COVID-19 has been a massive failure. In the 2020 edition of the Pew Research Center's survey of perceptions on China, global perceptions on China had soured noticeably from 2019, with China's role in the COVID-19 pandemic being the clear factor for this ${ }^{40}$. China's efforts to obfuscate the question of origins likely resulted in something of a 'Streisand effect' as it drew even more suspicion and scrutiny.

In the case of the second narrative battle, China has, indeed, won some international praise for its success in getting COVID-19 under control. In the same Pew survey, global perceptions were generally that China had done a better job in combatting COVID-19 than the United States, although both countries were judged more negatively than positively ${ }^{41}$. Problematically for China is that trust in $\mathrm{Xi}$ Jinping to do the right thing has reached all-time lows, meaning very few people expect China to do the right thing with regards COVID-19.

Although the relationship between China and the United States has devolved into much bickering, name-calling, and general nastiness since the onset of the COVID-19 pandemic, this kind of cyber-narrative competition, as worrying as it may be, is still not as hazardous as the

${ }^{40}$ Silver L., Devlin K., Huang C. Unfavorable Views of China Reach Historic Highs in Many Countries // Pew Research Center. October 6, 2020. URL: https://www.pewresearch.org/global/2020/10/06/unfavorab le-views-of-china-reach-historic-highs-in-many-countries/ (accessed: 20.01.2021).

${ }^{41}$ Ibid. envisaged scenarios of the Sino-American relationship offered by the new Cold War or new Peloponnesian War analogies.

Although the battle of narratives is fierce and somewhat unhinged, it will not necessarily bleed into the "real world", particularly as there still exists significant mediating factors that rationally preclude any serious conflict, such as ongoing trade interdependence (even after the trade wars), robust financial flows, the existence of nuclear weapons capabilities on both sides, and a lack of fervent popular support domestically on either side for a military conflict.

Nonetheless, one cannot overlook the importance of the "domestic games" both China and the United States have been playing and how this affects the Sino-American relationship. Trump's deflecting of the blame for the United States' poor handling of the pandemic by focusing on the origin of the virus in China and Xi's efforts to obfuscate the question of origins while focusing more on the success of China since the outbreak are both largely for domestic audiences. But such narratives come with significant implications for the "international games" both China and the United States have been playing and this is being especially felt in cyberspace at the moment. Conflict in cyberspace is a newish phenomenon and where this ongoing cyber conflict between China and the United States might head is hard to assert right now. However, this article contends that this will be the epicentre of Sino-American competition for the foreseeable future, rather than something more akin to a new Cold War or a new Peloponnesian War.

Received / Поступила в редакцию: 01.02.2021

Accepted / Принята к публикации: 02.04.2021

\section{References / Библиографический список}

Allison, G. (2017). Destined for war: Can America and China escape Thucydides's trap? Boston: Houghton Mifflin Harcourt.

Barrinha, A., \& Renard, T. (2017). Cyber-diplomacy: the making of an international society in the digital age. Global Affairs, 3(4-5), 353-364. https://dx.doi.org/10.1080/23340460.2017.1414924

Benedikt, M. (1994). Cyberspace: Some proposals. In M. Benedikt (Eds.), Cyberspace: First steps (pp. 119—224). Cambridge, MA: MIT Press. 
Bjola, C., \& Manor, I. (2018). Revisiting Putnam's two-level game theory in the digital age: Domestic digital diplomacy and the Iran nuclear deal. Cambridge Review of International Affairs, 31(1), 3-32. https://dx.doi.org/10.1080/09557571.2018.1476836

Bronfenbrenner, U. (1961). The mirror image in Soviet-American relations: A social psychologist's report. Journal of Social Issues, 17(3), 45-56. https://dx.doi.org/10.1111/j.1540-4560.1961.tb01682.x

Cartwright, M. (2020). Internationalising state power through the internet: Google, Huawei and geopolitical struggle. Internet Policy Review, 9(3), 1-18. https://dx.doi.org/10.14763/2020.3.1494

Choucri, N., \& Goldsmith, D. (2012). Lost in cyberspace: Harnessing the Internet, international relations, and global security. Bulletin of the Atomic Scientists, 68(2), 70-77. https://dx.doi.org/10.1177/0096340212438696

Clarke, M. (2017). The Belt and Road initiative: China's new grand strategy? Asia Policy, (24), 71-79. https://dx.doi.org/10.1353/asp.2017.0023

Demchak, C.C., \& Dombrowski, P.J. (2014). Rise of a cybered Westphalian age: The coming decades. In M. Mayer, M. Carpes \& R. Knoblich (Eds.), The global politics of science and technology (Vol. 1, pp. 91-113). Berlin: Springer. https://dx.doi.org/10.1007/978-3-642-55007-2_5

Diesen, G. (2021). Great power competition in the Fourth industrial revolution: The geoeconomics of technological sovereignty. London: Bloomsbury Publishing.

Grove, J. (2020). From geopolitics to geotechnics: Global futures in the shadow of automation, cunning machines, and human speciation. International Relations, 34(3), 432-455. https://dx.doi.org/10.1177/ 0047117820948582

Huseynov, V. (2019). Geopolitical rivalries in the "Common Neighborhood": Russia's conflict with the West, soft power, and neoclassical realism. Stuttgart: Ibidem Press.

Jaworsky, B.N., \& Qiaoan, R. (2020). The politics of blaming: The narrative battle between China and the US over COVID-19. Journal of Chinese Political Science. https://dx.doi.org/10.1007/s11366-020-09690-8

Krishna-Hensel, S.F. (2010). Technology and international relations. In R.A. Denemark \& R. Marlin-Bennett (Eds.), The International studies encyclopedia (Vol. 11, pp. 6947-6959). New York: Wiley-Blackwell.

Li, W. (2020). Why do we need to revisit the Cold War? China International Strategy Review, 2(1), 86-98. https://dx.doi.org/10.1007/s42533-020-00047-7

Limnéll, J. (2016). The cyber arms race is accelerating - what are the consequences? Journal of Cyber Policy, 1(1), 50-60. https://dx.doi.org/10.1080/23738871.2016.1158304

Meng, W. (2019). Unity, democracy, and anti-Americanism in China. The Washington Quarterly, 42(3), 121-135. https://dx.doi.org/10.1080/0163660X.2019.1664844

Middleton, B. (2017). A history of cyber security attacks: 1980 to present. Boca Raton: CRC Press.

Moore, G.J. (2017). Avoiding a Thucydides Trap in Sino-American relations (... and 7 reasons why that might be difficult). Asian Security, 13(2), 98-115. https://dx.doi.org/10.1080/14799855.2017.1286162

Moosa, I.A. (2020). The Thucydides Trap as an alternative explanation for the US-China trade war. Global Journal of Emerging Market Economies, 12(1), 42-55. https://dx.doi.org/10.1177/0974910119896644

Neumann, I.B. (2018). A prehistorical evolutionary view of diplomacy. Place Branding and Public Diplomacy, 14(1), 4 - 10. https://dx.doi.org/10.1057/s41254-017-0089-z

Polyakova, A., \& Boyer, S.P. (2018). The future of political warfare: Russia, the West, and the coming age of global digital competition. Washington, DC: Brookings Institution.

Rapkin, D.P., Thompson, W.R., \& Christopherson, J.A. (1979). Bipolarity and bipolarization in the Cold War era: Conceptualization, measurement, and validation. Journal of Conflict Resolution, 23(2), 261-295. https://doi.org/10.1177/002200277902300203

Sachs, J.D. (2019). Will America create a cold war with China. China Economic Journal, 12(2), 100-108. https://dx.doi.org/10.1080/17538963.2019.1601811

Schweller, R.L., \& Pu, X. (2011). After unipolarity: China's visions of international order in an era of US decline. International Security, 36(1), 41-72.

Smith, N.R. (2019). International order in the coming cryptocurrency age: The potential to disrupt American primacy and privilege? Rising Powers Quarterly, 3(1), 77-97.

Smith, N.R. (2020). A New Cold War? Assessing the current US - Russia relationship. Cham: Palgrave Pivot.

Smith, N.R., \& Fallon, T. (2020). An epochal moment? The COVID-19 pandemic and China's international order building. World Affairs, 183(3), 235-255. https://dx.doi.org/10.1177/0043820020945395

Thaliyakkattil, S. (2019). Introduction: The BRI as strategic camouflage. In S. Thaliyakkattil (Eds.), China's Achilles' heel: The Belt and Road Initiative and its Indian discontents (pp. 1-35). Singapore: Springer Singapore. https://dx.doi.org/10.1007/978-981-13-8425-7_1 
Yoder, B.K. (2019). Uncertainty, shifting power and credible signals in US - China relations: Why the "Thucydides Trap" is real, but limited. Journal of Chinese Political Science, 24(1), 87-104. https://dx.doi.org/ 10.1007/s11366-019-09606-1

Zhang, B. (2019). The perils of hubris? A tragic reading of "Thucydides' Trap" and China - US relations. Journal of Chinese Political Science, 24(1), 129-144. https://dx.doi.org/10.1007/s11366-019-09608-z

\begin{abstract}
About the authors: Smith Nicholas Ross - PhD, Associate Professor, Faculty of Humanities and Social Sciences, School of International Studies, University of Nottingham Ningbo China, Ningbo, China; ORCID: 0000-0003-1959-0365; e-mail: nr.smith@soverin.net

Brown Ruairidh John - PhD, International Studies Tutor, Centre for English Language Education, University of Nottingham Ningbo China, Ningbo, China; ORCID: 0000-0001-5492-3132; e-mail: ruairidh.brown@nottingham.edu.cn
\end{abstract}

Сведения об авторах: Смит Николас Росс - PhD, профессор факультета гуманитарных и социальных наук, Школа международных исследований Ноттингемского университета, кампус Нинбо, Нинбо, Китай; ORCID: 0000-0003-1959-0365; e-mail: nr.smith@soverin.net

Браун Руэрид Джон - $\mathrm{PhD}$, сотрудник центра обучению английскому языку Ноттингемского университета, кампус Нинбо, Нинбо, Китай; ORCID: 0000-0001-5492-3132; e-mail: ruairidh.brown@nottingham.edu.cn 